\title{
EKSTRAK KUNYIT PUTIH (CURCUMA ZEDOARIA (BERG) ROSCOE) SEBAGAI BAHAN PENGAWET SARI BUAH NANAS
}

\section{TURMERIC EXTRACT WHITE (CURCUMA ZEDOARIA (BERG) ROSCOE) AS PRESERVATIVE PINEAPPLE JUICE}

\author{
Suroto Hadi Saputra, Sugihartono \\ Balai Riset dan Standardisasi Industri Samarinda \\ Jalan Harmonika No. 3 Telp (0541) 732274 fax (0541) 745431 \\ roto_otor@yahoo.co.id
}

Naskah diterima 4 Oktober 2011, disetujui 12 Desember 2011

\begin{abstract}
ABSTRAK
Telah dilakukan penelitian tentang ekstrak kunyit putih (Curcuma zedoaria (Berg.) Roscoe) sebagai pengawet sari buah nanas. Tujuan penelitian untuk memperoleh kemampuan ekstrak kunyit putih (Curcuma zedoaria (Berg.) Roscoe) untuk menghambat pertumbuhan mikroba pada sari buah nanas. Rimpang kunyit putih dibuat bubuk kemudian dtimbang 250 gram bubuk kunyit putih lalu dilarutkan dengan pelarut etanol absolut $500 \mathrm{ml}$, diamkan (24 jam). Kemudian disaring dengan menggunakan kertas saring $\Phi 42 \mathrm{~mm}$, hasil saringan (flitrat) diuapkan dengan evaporator guna diperoleh cairan kental. Cairan kental di oven vacuum hingga terbentuk ekstrak kunyit putih kering. Ekstrak kunyit putih (Curcuma zedoaria (Berg.) Roscoe) ditambahkan ke dalam minuman sari buah nanas dengan konsentrasi $600 \mathrm{mg} / \mathrm{L}, 650 \mathrm{mg} / \mathrm{L}$, tanpa perlakuan (kontrol) dan sebagai bahan pembanding digunakan asam sorbat dengan konsentrasi $600 \mathrm{mg} / \mathrm{L}$. Dari hasil uji coba tersebut diketahui bahwa penambahan $650 \mathrm{mg}$ eksrak kunyit putih ke dalam 1 liter sari buah nanas mampu mempertahankan umur simpan sari buah nanas hingga 30 hari. Hasil penelitian juga menunjukan tidak adanya pertumbuhan cemaran bakteri jenis Salmonella, Escherichia Coli, Staphylococcus aureus dan Bacilus cereus di dalam minuman sari buah nanas.
\end{abstract}

Kata kunci : Curcuma zedoaria, ekstrak, pengawet, sari buah nanas

\section{ABSTRACT}

A study on white turmeric extract (Curcuma zedoaria (Berg.) Roscoe) pineapple juice as a preservative. Research objectives were to acquire the ability of white turmeric extract (Curcuma zedoaria (Berg.) Roscoe) to inhibit microbial growth in pineapple juice. Turmeric rhizome was made of white powder, weighing 250 grams of white turmeric powder and then dissolved with a solvent absolute ethanol $500 \mathrm{ml}$, let stand (24 hours), then filtered using filter paper $\Phi 42 \mathrm{~mm}$. The flitrat was evaporated by vaccum evaporator to obtain a viscous liquid, the dried vacuum oven to get powder. The white turmeric extract (Curcuma zedoaria (Berg.) Roscoe) was added to drink pineapple juice with a concentration of 600 $\mathrm{mg} / \mathrm{L}, 650 \mathrm{mg} / \mathrm{L}$, no treatment (control) and as a comparison material used sorbic acid with a concentration of $600 \mathrm{mg} / \mathrm{L}$. Results showed that the addition of $650 \mathrm{mg}$ extract white turmeric into 1 quart pineapple juice is able to get the shelf life of pineapple juice up to 30 days. By this treatment the results also showed no growth of bacterial contamination of Salmonella species, Escherichia Coli, Staphylococcus aureus and Bacilus cereus in the drink pineapple juice.

Keywords : curcuma zedoaria, extracts, preservatives, pineapple juice 


\section{PENDAHULUAN}

A da 7 (tujuh) agenda riset nasional 2010-2014 antara lain ketahanan pangan, energi, teknologi informasi dan komunikasi, teknologi manajemen dan transportasi, teknologi pertahanan dan keamanan, teknologi kesehatan dan obat, dan material maju. (Dewan Riset Nasional, 2009).

Terkait dengan ketahanan pangan ada empat hal antara lain pasokan bahan pangan, pasokan bahan jenis tertentu, kekurangan gizi, dan penggunaan bahan kimia. Penggunaan bahan kimia sebagai bahan pengawet pangan sebagaimana diatur oleh Menteri kesehatan RI. Lampiran nomor 722/menkes/per/IX/1988. (Proyek Pemberdayaan Industri Kecil dan Menengah, 2002).

Bahan pengawet yang digunakan dewasa ini berasal dari bahan sintetis. Khususnya untuk bahan pengawet minuman (sari buah) digunakan jenis bahan pengawet sintetis yaitu asam sorbat, $\mathrm{Na} / \mathrm{K}$ Sorbat, asam benzoate, ester asam $\mathrm{p}$-hidroksi benzoate (Proyek Pemberdayaan Industri Kecil dan Menengah, 2002).

Hasil olahan pangan baik berupa makanan maupun minuman menghendaki masa simpan yang lama. Untuk mempertahankan masa simpan yang lama tersebut biasanya di dalam produk olahan pangan baik makanan dan minuman ditambahkan dengan zat pengawet.

Usaha-usaha untuk mencari bahan pengawet altrnatif yang berasal dari alam terus dilakukan oleh para peneliti, agar diperoleh bahan pengawet yang berasal dari tanaman sehingga aman bagi kesehatan manusia. Salah satu tanaman yang memungkinkan sebagai bahan pengawet alternatif adalah rimpang kunyit putih (Curcuma zedoaria (Berg.) Roscoe).

Ekstrak rimpang kunyit putih (Curcuma zedoaria (Berg.) Rocoe) mengandung zat pati, mineral, lemak, saponin, flavonoid, polifenol dan triterpenoid (Syukur dkk, 2003).

Menurut Suroto HS dan Yustini (2008) ekstrak rimpang kunyit putih (Curcuma zedoaria (Berg.) (Roscoe) yang dilarutkan degan pelarut metanol dan etanol mampu menghambat pertumbuhan bakteri pencemar $>50 \%$ antara lain Salmonella, Bacillus cereus dan mampu mematikan $100 \%$ larva Artemia.

Adapun tujuan penelitian ini adalah untuk memperoleh kemampuan ekstrak kunyit putih (Curcuma zedoaria (Berg) (Roxby) untuk menghambat pertumbuhan mikroba sari buah nanas.

\section{BAHAN DAN METODE}

\section{Bahan dan Alat Penelitian}

Bahan yang digunakan dalam penelitian ini antara lain rimpang kunyit putih (Curcuma zedoaria (Berg.) Roscoe) diperoleh di pasar, botol, label nama, kain saringan, buah nanas, gula putih dan aquades. Bahan kimia yang digunakan antara lain etanol (p.a) dan asam sorbat (p.a). Sedangkan alat yang digunakan dalam penelitian ini antara lain blender, toples, neraca analitik, kertas saring, gelas bejer, gelas ukur, labu ukur, batang pengaduk, corong pisah, alat pemanas, penguap putar vakum (rotary vacuum evaporator), sheker, oven vacuum, dan desikator.

\section{Metode}

Persiapan bahan baku yaitu rimpang kunyit putih dikupas, lalu dicuci bersih dan diiris tipis-tipis, kemudian dikeringkan dengan oven pada suhu $50^{\circ} \mathrm{C}$ sampai rimpang kering atau sampai diperoleh kadar air rimpang konstan ( $\pm 20 \%)$. Kemudian dilakukan penggilingan kering dengan blender, selanjutnya di ayak dengan ukuran 60 mesh. Sehingga diperoleh bubuk rimpang kunyit putih. 
Ekstraksi dilakukan dengan cara menimbang bubuk rimpang kunyit putih sebanyak 250 gram, masukkan kedalam labu ekstrak, tambahkan etanol sebanyak $500 \mathrm{ml}$, kemudian homogenkan menggunakan sheker selama 24 jam dengan kecepatan 150 rpm. Setelah 24 jam lakukan penyaringan dengan kertas saring, agar proses penyaringan cepat dapat di bantu dengan penyaringan vakum. Filtrat hasil penyaringan dikumpulkan dalam satu wadah kemudian pelarutnya diuapkan dengan menggunakan rotary vacuum evaporator dengan suhu $50^{\circ} \mathrm{C}$ sampai tidak ada pelarut yang menguap. Selanjutnya ekstrak di oven vakum kembali agar diperoleh ekstrak rimpang kunyit putih kasar.

Selanjutnya botol dan tutup botol dicuci bersih dengan menggunakan sabun cuci dan bilas sampai bersih, lalu tiriskan/ dikeringangin kan sampai tidak ada air yang menempel di botol. Botol dan tutupnya yang sudah kering dibungkus dengan kertas kemudian di oven pada suhu $150^{\circ} \mathrm{C}$ selama 2 jam.

Tahap selanjutnya membuat sari buah nenas yaitu buah nanas yang digunakan dalam penelitian ini berasal dari pedagang buah/penjual buah di pasar. Buah nanas dipilih dengan kriteria matang, tidak cacat dan bebas dari hama dan penyakit. Buah nanas dibersihkan dengan membuang tangkai, daun, kulit dan mata buah nenas. Buah nanas dicuci hingga bersih dengan air yang mengalir, dipotong-potong kecil kemudian diblender tanpa penambahan air, setelah itu disaring menggunakan kain saring, penyaringan dilakukan untuk memisahkan filtrat dengan ampas nanas. Filtrat yang diperoleh kemudian dimasukkan ke dalam panci, lalu tambahkan air bersih dengan perbandingan 11 liter sari buah dan 5 liter air bersih. Sari buah nanas dipanaskan pada suhu $90^{\circ} \mathrm{C}$ aduk perlahan sampai 10 menit, saribuah nanas didinginkan untuk mengendapkan padatan yang masih tersisa. Endapan yang terdapat pada kain saring disatukan dengan ampas nenas hasil blender untuk dimanfaatkan menjadi selai nanas.

Aplikasi ekstrak dengan cara sari buah nanas yang telah jernih diberi tambahan gula pasir dengan perbandingan 14 liter sari buah nanas dan $2 \mathrm{~kg}$ gula pasir, selanjutnya diaduk dan dipanaskan kembali selama \pm 10 menit, lalu Sari buah nanas di bagi menjadi 4, satu bagian ditambahkan ekstrak kunyit putih (EKP) dengan konsentrasi $600 \mathrm{mg}$ EKP /liter sari buah nanas, $650 \mathrm{mg} E K P / l i t e r$ sari buah nanas, untuk kontrol sari buah nanas tidak ditambahkan pengawet apapun, dan satu bagian terakhir ditambahkan asam sorbat (AS) dengan konsentrasi $600 \mathrm{mg} \mathrm{AS/liter} \mathrm{sari} \mathrm{buah} \mathrm{nanas,} \mathrm{asam}$ sorbat digunakan sebagai pembanding. Selanjutnya dalam keadaan masih panas semua perlakuan dimasukkan ke dalam botol yang telah disterilisasi, botol-botol diberi label atau kode sesuai dengan perlakuan yang diujicobakan, pengerjaan dilakukan secara aseptik untuk mengurangi kemungkinan terjadinya kontaminasi.

\section{HASIL DAN PEMBAHASAN}

Hasil penelitian pemanfaatan ekstrak kunyit putih (Curcuma zedoaria (Berg.) Roscoe) sebagai bahan pengawet pada sari buah nanas sebagaimana pada Tabel 1, 2, 3, dan 4.

Keadaan sari buah nanas pada umur simpan 30 dan 60 hari setelah perlakuan sebagaimana pada Tabel 1 dan 2. 
Tabel 1. Keadaan Sari Buah Nanas Pada Umur Simpan 30 Hari Setelah Perlakuan

\begin{tabular}{lccc}
\hline \multicolumn{1}{c}{ Perlakuan } & Warna & Bau & Keadaan \\
& Normal & Normal, khas nanas & Normal, khas nanas \\
\hline Kontrol & Normal & Normal, khas nanas & Normal, khas nanas \\
$600 \mathrm{mg}$ AS / L SBN & Normal & Normal, khas nanas & Normal, khas nanas \\
$600 \mathrm{mg}$ EKP / L SBN & Normal & Normal, khas nanas & Normal, khas nanas \\
$650 \mathrm{mg} \mathrm{EKP} \mathrm{/} \mathrm{LSBN}$ & .
\end{tabular}

Tabel 2. Keadaan Sari Buah Nanas Pada Umur Simpan 60 Hari Setelah Perlakuan

\begin{tabular}{lccc}
\hline \multicolumn{1}{c}{ Perlakuan } & Warna & Bau & Keadaan \\
& Normal & Normal, khas nanas & Normal, khas nanas \\
\hline Kontrol & Normal & Normal, khas nanas & Normal, khas nanas \\
$600 \mathrm{mg}$ AS / L SBN & Normal & Normal, khas nanas & Normal, khas nanas \\
$600 \mathrm{mg}$ EKP / L SBN & Normal & Normal, khas nanas & Normal, khas nanas \\
$650 \mathrm{mg} \mathrm{EKP} \mathrm{/} \mathrm{LSBN}$ & . & \\
\hline
\end{tabular}

Keterangan: $\quad A S=$ Asam Sorbat

SBN = Sari buah nanas

$\mathrm{EKP}=$ Ekstrak kunyit putih

Berdasarkan hasil analisa aktivitas ekstrak rimpang kunyit putih terhadap keadaan (warna, bau dan rasa) sari buah nanas umur 30 dan 60 hari sebagaimana tabel 1 dan 2 bahwa warna normal, bau dan rasa normal, khas sari buah nanas. Syarat mutu sari buah mempersyaratkan untuk keadaan warna normal, bau dan rasa normal dan khas buah bahan baku aslinya. Syarat mutu sari buah tomat mempersyaratkan mutu keadaan warna normal, bau dan rasa normal dan khas tomat (SNI 014867.1-1998). Syarat mutu sari buah anggur mempersyaratkan mutu keadaan warna normal, bau dan rasa normal dan khas anggur (SNI 01-4867.2-1998). Syarat mutu sari buah apel mempersyaratkan mutu keadaan warna normal, bau dan rasa normal dan khas apel (SNI 01-4867.3-1998).

1. Aktivitas ekstrak kunyit putih terhadap cemaran mikroba sari buah nanas pada umur simpan 30 dan 60 hari setelah perlakuan sebagaimana pada Tabel 3.

Tabel 3. Aktivitas Kunyit Putih Terhadap Jenis Cemaran Mikroba Sari Buah Nanas Pada Umur Simpan 30 Dan 60 Hari Setelah Perlakuan.

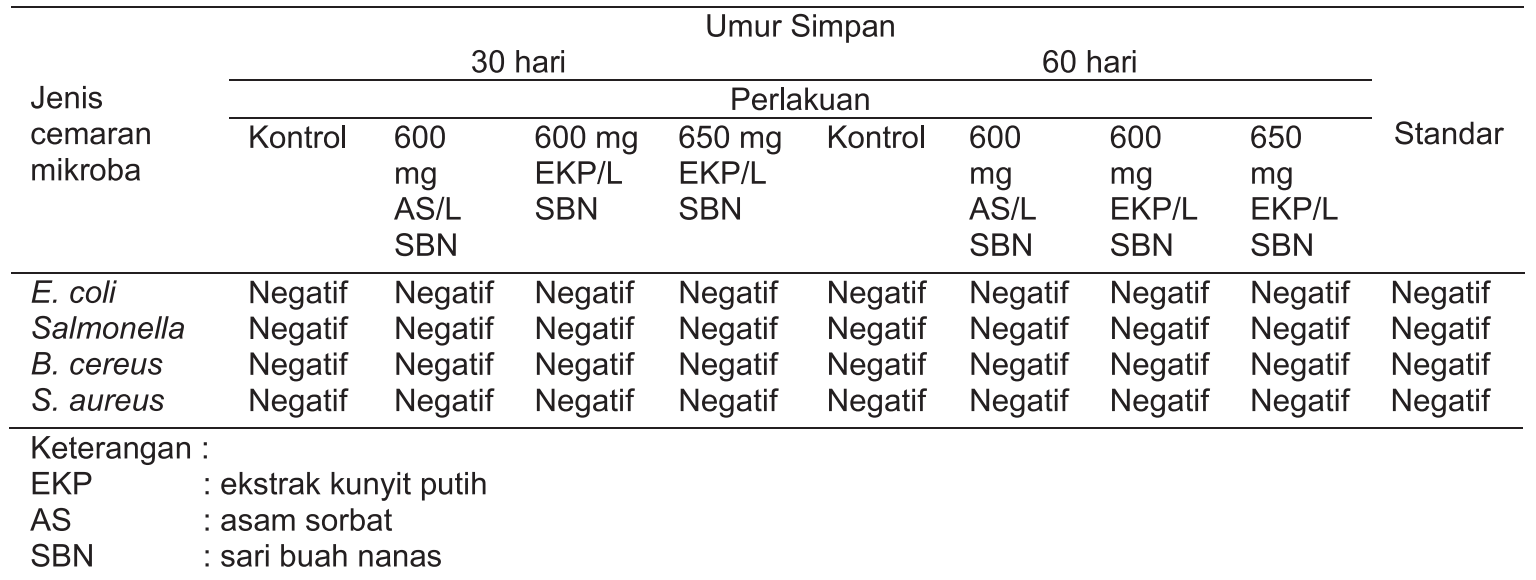

Hasil analisa ekstrak rimpang kunyit putih terhadap jenis cemaran mikroba sari buah nanas umur simpan 30 dan 60 hari tidak terdapat jenis 
cemaran mikroba bakteri $E$. coli, Salmonella, B. cereus dan S. aureus baik pada perlakuan dengan penambahan pengawet asam benzoat, ekstrak rimpang kunyit putih maupun tanpa pengawet sebagaimana tersaji pada tabel 3. Hal ini diduga bahwa pada saat pembuatan sari buah nanas bahan dan alat yang digunakan tidak tercemar bakteri/mikroba jenis $E$. coli, Salmonella, B. cereus dan S. aureus. Menurut Irianto (2006) menyatakan infeksi oleh bakteri genus Salmonella menyerang saluran gastrointestin yang mencakup perut, usus halus dan usus besar atau kolon. Penjangkitan Salmonellosis karena makanan bersifat eksplosif, dan kaitannya dengan pesta perkawinan, penjamuan makan atau peristiwa lain yang menyajikan hidangan untuk sekelompok orang. Makanan yang biasanya tercemar meliputi kue-kue yang mengandung saus, susu, daging cincang, sosis unggas, daging panggang yg diperdagangkan, dan telur. Walaupun penular dan orang sakit dapat mencemari makanan dan minuman, sumber Salmonellosis tersebar yang merupakan gudang Salmonella ialah hewan tingkat rendah. Salmonella terdapat secara alamiah pada ayam, kalkun, bebek, kucing, anjing, kura-kura dan banyak lagi hewan lainnya.
Lebih lanjut untuk Staphylococcus aueus yang tumbuh pada makanan tercemar. Staphylococcus adalah organisme yang umumnya terdapat di berbagai bagian tubuh manusia, termasuk hidung, tenggorokan, kulit, dan karenanya mudah masuk makanan. Beberapa bakteri lain yang juga dianggap sebagai penyebab peracunan makanan meliputi Bacillus cereus, galurgalur tertentu misalnya Escherichia coli.

Menurut Pelczar dan Chan (1988) menyatakan $E$. coli adalah penghuni normal saluran pencernaan manusia dan hewan berdarah panas. Mikroorganisme indikator sebagaimana digunakan dalam air mengacu pada sejenis mikroorganisme yang kehadirannya di dalam air tersebut terpolusi oleh bahan tinja dari manusia atau hewan berdarah panas. Terdapat peluang bagi berbagai macam mikroorganisme patogenik, yang secara berkala terdapat dalam saluran pencernaan, untuk masuk ke dalam air tersebut.

2. Aktivitas ekstrak kunyit putih terhadap cemaran mikroba dan $\mathrm{pH}$ sari buah nanas pada umur simpan 30 dan 60 hari setelah perlakuan sebagaimana pada Tabel 4.

Tabel 4. Aktivitas Ekstrak Kunyit Putih Terhadap Cemaran Mikroba Dan pH Sari Buah Nanas Pada Umur Simpan 30 dan 60 Hari Setelah Perlakuan.

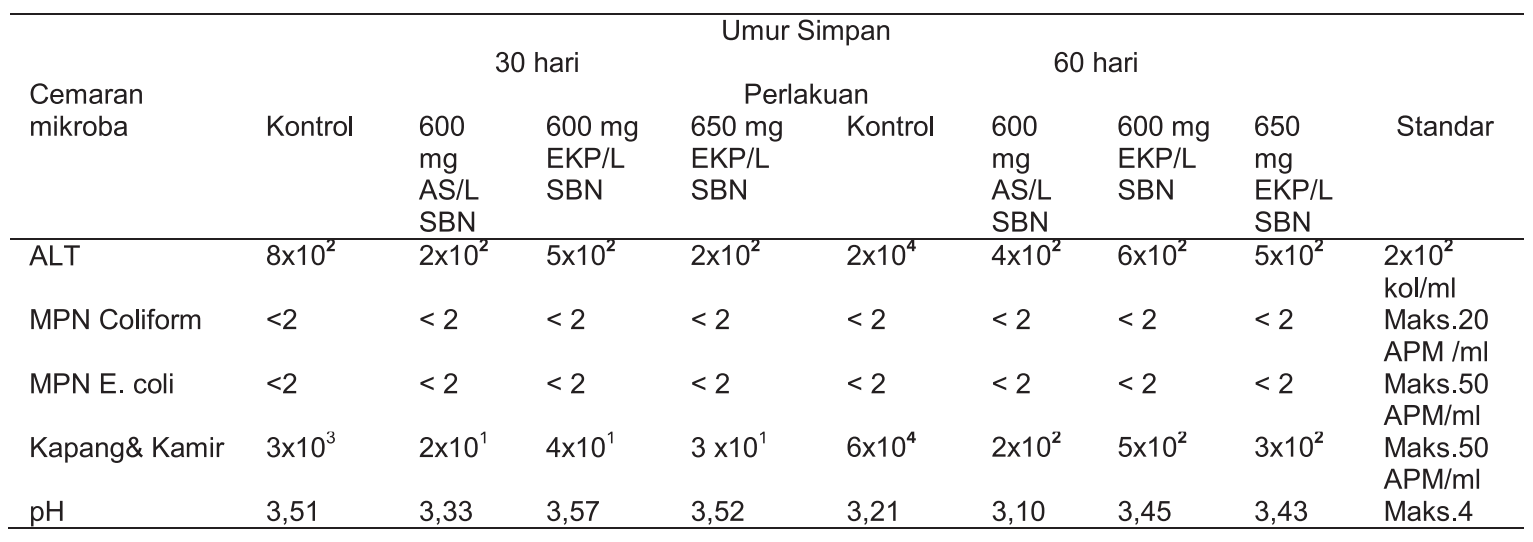

Keterangan :

ALT : Angka lempeng total

AS : Asam Sorbat

SBN : Sari buah nanas

EKP : Ekstrak kunyit putih 
Berdasarkan hasil analisa ekstrak rimpang kunyit putih terhadap cemaran mikroba sari buah nanas umur 30 dan 60 hari sebagaimana tabel 7,8 dan 9 bahwa pada umur simpan 30 dan 60 hari sampel tanpa pemberian pengawet (kontrol) menunjukkan adanya pertumbuhan mikroba, hal ini dapat dilihat dari hasil uji parameter ALT/TPC, hasil uji menunjukkan bahwa kontrol mempunyai pertumbuhan mikroba yang paling tinggi diikuti oleh perlakuan $600 \mathrm{mg} / \mathrm{L}$ SBN, lalu perlakuan $650 \mathrm{mg} / \mathrm{L}$ dan Asam Sorbat $600 \mathrm{mg} / \mathrm{L}$ keduanya mempunyai nilai cemaran yang hampir sama. Hal ini menunjukkan bahwa perlakuan $600 \mathrm{mg} / \mathrm{L}$ belum mampu menahan pertumbuhan mikroba setelah umur simpan selama 30 hari, sedangkan untuk perlakuan $650 \mathrm{mg} / \mathrm{L}$ hasil ujinya sudah sama dengan perlakuan Asam Sorbat $600 \mathrm{mg} / \mathrm{L}$.

Hasil uji kapang dan kamir untuk kontrol lebih tinggi dibandingkan dengan pemberian pengawet asam sorbat dan ekstrak rimpang kunyit putih. Hal ini diduga bahwa pemberian pengawet asam sorbat dan ekstrak rimpang kunyit putih memberikan antimikroba terhadap penghambatan aktivitas cemaran kapang dan khamir pada sari buah nanas.

Hasil analisa rimpang kunyit putih memiliki senyawa fenol $0,798 \mu \mathrm{g} / \mathrm{ml}$, Senyawa fenolik tanaman yang telah terbukti memiliki aktivitas antibakteri, diantaranya adalah turunan dari $\mathrm{p}$ benzekuinon seperti 2,3-dimetoksi-5metil-pbenzokuinon, 2,6-difenil-pbenzekuinon, dan 2,6-dimetoksi-pbenzekuinon (Nishina et al., 1991).

Hasil penelitian ekstrak kunyit putih terhadap $\mathrm{pH}$ sari buah nanas umur 30 dan 60 hari terlihat adanya kecendrungan penurunan sebagaimana tersaji pada tabel 4. Namun bila dibandingkan dengan persyaratan Standar Nasional Indonesia untuk sari buah secara umum masih memenuhi syarat, dimana syarat maks. $\mathrm{pH} 4$. Syarat mutu sari buah tomat mempersyaratkan $\mathrm{pH}$ maks.4 (SNI 01-
4867.1-1998). Syarat mutu sari buah anggur mempersyaratkan $\mathrm{pH}$ maks. 4 (SNI 01-4867.2-1998). Syarat mutu sari buah apel mempersyaratkan $\mathrm{pH}$ maks. 4 (SNI 01-4867.3-1998).

\section{KESIMPULAN DAN SARAN}

Berdasarkan hasil penelitian yang telah dilakukan dapat disimpulkan bahwa Ekstrak kunyit putih mampu menghambat serangan mikroba hingga umur simpan 30 hari pada konsentrasi $650 \mathrm{mg} / \mathrm{L}$, kecuali parameter ALT.

Disarankan dalam penerapan ekstrak kunyit putih dilarutkan dengan air panas terlebih dahulu agar tercampur secara baik di dalam sari buah nanas.

\section{DAFTAR PUSTAKA}

Badan Standardisasi Nasional-BSN. 1998. SNI 01-4867.1-1998. Sari Buah Tomat. Badan Standardisasi Nasional-BSN. Jakarta.

Badan Standardisasi Nasional-BSN. 1998. SNI 01-4867.2-1998. Sari Buah Anggur. Badan Standardisasi Nasional-BSN. Jakarta.

Badan Standardisasi Nasional-BSN. 1998. SNI 01-4867.3-1998. Sari Buah Apel. Badan Standardisasi Nasional-BSN. Jakarta.

Dewan Riset Daerah. 2009. Agenda Riset Nasional. Dewan Riset Daerah. Jakarta.

Irianto K. 2006. Mikrobiologi Jilid 2. CV. Yrama Widya. Bandung.

Nishina, A.K., Kinaichi, H., Uchiboni, T., Seino, H., and Osawa T. $1991 . \quad$ 2,6-dimethoxy-pbenzequinone as an antimicrobial subtance in the bark of Phyllostachys heterocycla var. Pubscens a species of thick-stemmed bambo. J Agric Food Chem 39.

Pelczar J. M dan Chan E.C.S. 1988. Dasar-Dasar Mikrobiologi Jilid 2. Universitas Indonesia. Jakarta. 
Proyek Pemberdayaan Industri Kecil dan Menengah. 2002. Panduan Penerapan Bahan Tambahan Pangan. Direktorat Jenderal Industri dan Dagang Kecil dan Menengah, Departemen Perindustrian dan Perdagangan. Jakarta.

Suroto HS., dan Yustini, E.P. 2008. Laporan Penelitian Analisa Fitokimia Kunyit Putih untuk Bahan Baku Industri. Balai Riset dan Standardisasi Industri Samarinda. Samarinda.

Syukur C, Udarno L dan Taryono. 2003. Keragaan Kunyit Putih (Curcuma zedoaria, Curcuma mangga, Kaempferia rotunda). Proseding Seminar dan Pameran Nasional Tumbuhan Obat Indonesia. Jakarta.

Yuliarti N. 2007. Awas Bahaya di Balik Lezatnya Makanan. Andi. Yogyakarta. 